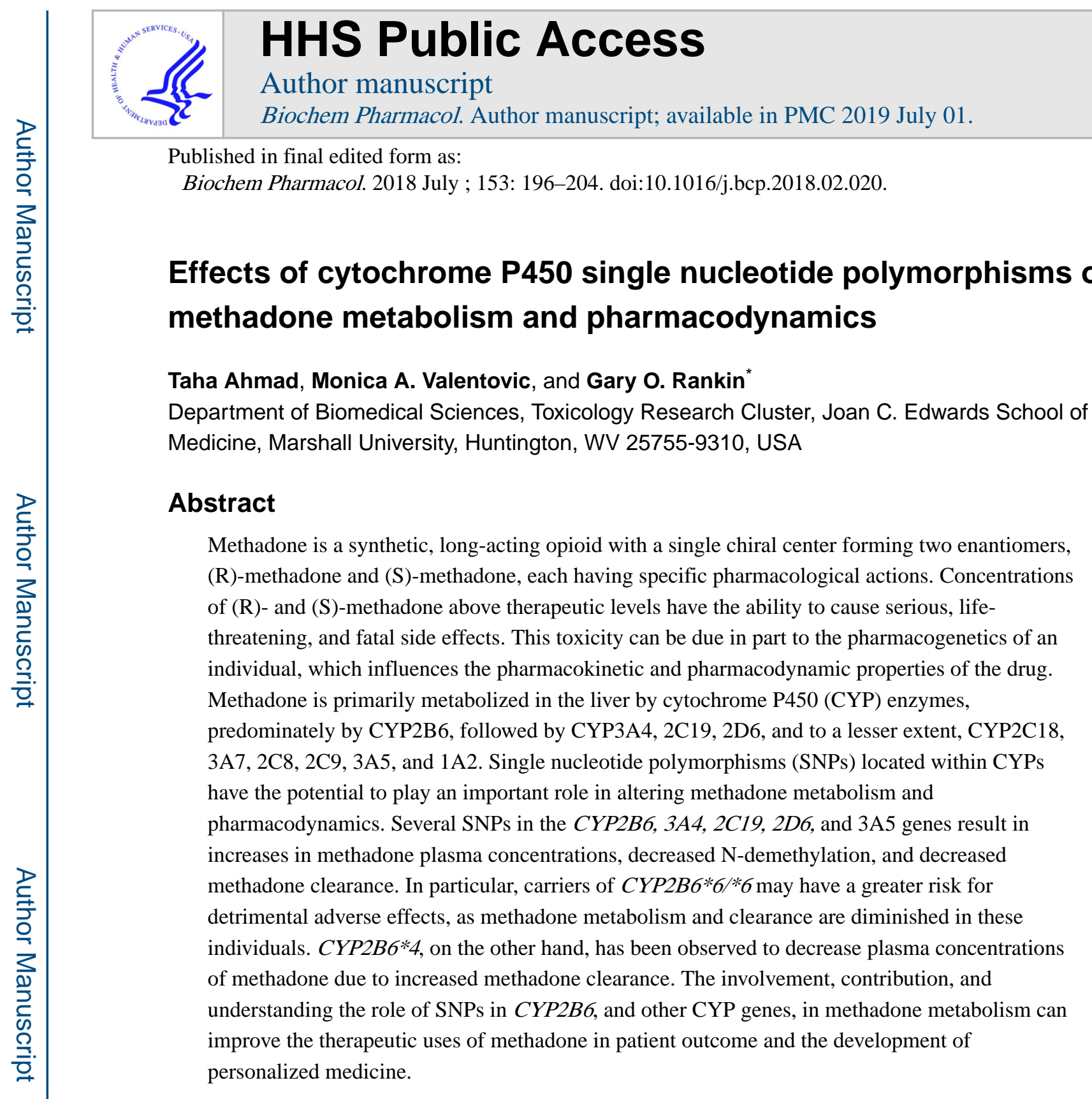

\title{
Keywords
}

Methadone metabolism; Single nucleotide polymorphism (SNP); Cytochrome P450 (CYP); Pharmacogenetics; Genetic variant

\section{Methadone pharmacology}

Shortly after methadone was introduced in the United States, the Food and Drug Administration (FDA) approved its use as an analgesic and antitussive agent [1]. During the 1960s, evidence for the usefulness of methadone in the treatment of and maintenance

\footnotetext{
"Corresponding author at: Department of Biomedical Sciences, Joan C. Edwards School of Medicine, BBSC-435F, Marshall University, 1700 Third Avenue, Huntington, WV 25755, USA. rankin@ marshall.edu.

Conflict of interest

The authors declare no conflict of interest.
} 
therapy for narcotic addiction was growing [2,3]. A decade later, the FDA expanded the approval for physicians and hospital pharmacies to dispense methadone for treating opiate addiction in treatment programs only [1]. Enrollment in a methadone maintenance treatment (MMT) program also has the potential to be a public health strategy for decreasing the transmission of infectious diseases (e.g. HIV/AIDS, hepatitis C, or other blood-borne pathogens) by reducing the number of opioid users reusing contaminated needles [3-5].

Methadone is a synthetic, long-acting opioid with a single chiral center that forms two enantiomers, R-(-)-methadone (levo-methadone) and S-(+)-methadone (dextro-methadone) [6,7]. Both enantiomers have specific pharmacodynamic properties and pharmacological actions. (R)-Methadone is a $\mu$-opioid receptor (MOR) agonist that mimics the body's natural endogenous opioids, endorphins and enkephalins.Binding of (R)-methadone to the MOR mediates therapeutic effects with the release of other neurotransmitters, including acetylcholine, dopa-mine, norepinephrine, and substance $\mathrm{P}$ [6]. The effects propagated by this interaction yields reduction and elimination of drug cravings and withdrawal signs and symptoms of narcotics, analgesia, sedation, nausea, vomiting, constipation, miosis, antitussive effects, hypotension, mild bradycardia, and tolerance and dependence [8-11].

In the United States, methadone is clinically available only as a racemic formulation comprised of both (R)- and (S)-methadone enantiomers [12-14]. Methadone is currently used as: (1) an approved opioid substitution therapeutic agent to suppress opioid-abstinence syndrome in opiate abuse and addiction [15-19]; (2) a second-line opioid in alleviating cancer pain and chronic non-malignant pain, such as back, joint, or neuropathic pain and other forms of severe pain [20-23]; and (3) a first-line treatment in patients with both opioid dependence and chronic pain [24].

Methadone has contributed to a significant portion of opioid-related overdose deaths. However, this outcome is not attributed to the use of methadone for opioid dependence, rather from prescriptions of methadone for pain management [25]. Reports from the Centers for Disease Control and Prevention (CDC) indicate a 15.6\% increase in opioid death rates from 2014 to 2015 . Conversely, methadone death rates decreased by $9.1 \%$ due to factors such as efforts to reduce methadone therapy for pain, warning labels, clinical guidelines, and limiting high dose formulations [26]. However, death rates continued to increase through 2014 resulting from methadone overdosing in individuals between the ages of 55-64 years [25].

Concentrations of (R)- and (S)-methadone above therapeutic levels have negative and detrimental side effects. Elevated (R)-methadone levels may depress ventilation, inducing respiratory depression, by acting on the MORs expressed on respiratory centers in the brainstem [27-29]. Conversely, an increase in (S)-methadone disposition causes cardiotoxicity through the blockage of the voltage-gated potassium channel of the human ether-a-go-go related gene (hERG), subsequently prolonging the QT interval of an electrocardiogram leading to torsades de pointes. (S)-Methadone is 3.5 times more potent than (R)-methadone in blocking the hERG channel, thus attributing the stereoselectivity of methadone to cardiotoxicity [30-33]. 
Methadone is primarily eliminated via hepatic metabolism by cytochrome P450 (CYP) enzymes through oxidative biotransformation. Methadone undergoes stereoselective Ndemethylation followed by spontaneous cyclization to form the principle, inactive metabolite 2-ethyl-1,5-dimethyl-3,3-diphenylpyrrolidine (EDDP) (Fig. 1) [34-39].Methadone has a broad half-life of elimination ranging from 5 to $130 \mathrm{~h}$, with an average of $22 \mathrm{~h}$ [40]. This extreme inconsistency in the elimination half-life exemplifies the large variability methadone possesses in its pharmacokinetics between individuals. Because of the interindividual variation, it is difficult to predict an individual's peak plasma levels, which may result in some individuals having a higher than normal plasma level that approaches the toxic or even fatal drug concentration. Co-medication, age, gender, health, weight, and ethnicities can all be factors that contribute to this effect.

Genetic variation occurs within and among populations, leading to polymorphisms. Single nucleotide polymorphisms (SNPs) are the most common type of genetic variation. A SNP is a variation of a single nucleotide at a specific position in the genome, some of which may contribute to changes in a gene, either in the coding (exons) or non- coding (introns) regions, or the regions between genes. A genetic variation within CYP genes responsible for the metabolism of methadone may be causal for altered function, which may result in methadone being rapidly eliminated from the body, thus preventing the drug from reaching therapeutic levels. Alternatively, the genetic variation may prolong elimination from the body, consequently, intensifying analgesic and detrimental adverse effects [41,42]. The purpose of this review is to focus on the effects of SNPs of the various CYPs that metabolize methadone.

\section{Methadone metabolism}

Eleven metabolites from methadone metabolism have been isolated and identified in urine and feces in humans [43]. Methadone predominantly forms the pharmacologically inactive pyrrolidine metabolites EDDP and 2-ethyl-5-methyl-3,3-diphenylpyrroline (EMDP). Methadol and normethadol are active analgesic metabolites of methadone, although this pathway is relatively minor [44,45]. To a lesser extent, methadone, normethadol, EDDP, and EMDP are further hydroxylated to form inactive $p$-hydroxy metabolites. Another minor pathway yields the inactive metabolites 4-dimethylamino-2,2-diphenylvaleric acid, 4methylamino-2,2-diphenylvaleric acid, and 1,5-dimethyl-3,3-diphenyl-2-pyrrolidone (Fig. 1) [43-45].

The CYP enzymes involved in the formation of methadone meta-bolites in humans are CYP2B6, 3A4, 2C19, 2D6, and to a lesser extent, CYP2C18, 3A7, 2C8, 2C9, 3A5, and 1A2 [46]. These CYPs, however, metabolize methadone in a stereoselective manner, where CYP2C19, 3A7, and 2C8 preferentially metabolize (R)-methadone, CYP2B6, 2D6, and $2 \mathrm{C} 18$ primarily metabolize (S)-methadone, and CYP3A4 demonstrates no stereoselectivity in methadone metabolism [46,47]. Methadone is $\mathrm{N}$-demethylated to an intermediate compound, normethadone, which is then spontaneously cyclized to form EDDP. A second N-demethylation reaction occurs on EDDP to form EMDP [35-37,44,48]. An alternate metabolic pathway in the formation of EMDP is a CYP mediated N-demethlyation of normethadone to form dinormethadone, which is then spontaneously cyclized to EMDP 
[47]. In a minor bio-transformation pathway, the keto group of methadone is reduced by alcohol dehydrogenase to form methadol, which can be N-demethylated to form normethadol. The inactive (S)-methadone produces active metabolites of $a-1$-methadol and $a$-l-normethadol, which have analgesic properties comparable to (R)-methadone. (R)Methadone, on the other-hand, is metabolized to biologically inactive metabolites of $d$ methadol and $d$-normethadol $[44,45,47]$.

Methadone's long ranging half-life can be partially attributed to the extreme interindividual pharmacokinetics and its stereoselective metabolism [49,50]. (S)-Methadone exhibits a significantly shorter elimination half-life than (R)-methadone [48,51]. Inherited polymorphisms in CYPs have the potential to affect the metabolic rate of methadone in a stereoselective manner. The following sections will discuss the role of CYP SNPs in methadone metabolism and its consequences on biological activity.

\section{Cytochrome P450 (CYP)}

There are approximately 57 active human CYP genes grouped into 18 families and 44 subfamilies. Only 12 CYP enzymes, which belong to the CYP1, CYP2, or CYP3 families, are of major importance and responsible for the metabolism of more than $95 \%$ of therapeutic drugs [52-54]. The involvement and contribution of SNPs is inadequately understood in drug biotransformation, but are known to play a vital role in the differences in patient outcome and the development of personalized medicine [55]. SNPs can cause a loss of function mutation, in which the splicing, expression, or transcription of the CYP gene is decreased or the protein structure is altered. Alternatively, gain of function mutations may also occur, resulting in an increased substrate turnover due to an increased number of functional gene copies, as well as variations in the promotor or amino acids [54,56,57]. SNPs may be responsible for determining metabolic phenotype - ultra-rapid metabolizers (UMs), extensive metabolizers (EMs), intermediate metabolizers (IMs), and poor metabolizers (PMs) - and the binding affinity to CYPs, all while affecting the half-life, as well as the therapeutic and detrimental effects of methadone.

\subsection{CYP1 family}

The CYP1 family consists of two subfamilies, encompassing three functional genes, CYP1A1, 1A2, and 1B1. CYP1A1 and CYP1B1 enzymes are mainly expressed extrahepatically, whereas CYP1A2 accounts for $4-16 \%$ of the hepatic CYPs and is responsible for $8-10 \%$ of the drugs metabolized by CYP isoforms, including methadone $[41,54,58]$.

The interindividual variations in the mRNA and protein expression levels of CYP1A2 range from 15 to 40 fold, and a 40-130 fold inter-individual difference in activity [59]. To date, there are 190 genetic variants in CYP1A2 [60,61]. An in silico study, by Wang et al. [52], found 31 nonsynonymous SNPs, of which 24 were predicted to be deleterious by the SIFT and PolyPhen algorithms. (S)-Methadone is marginally metabolized by CYP1A2 [46,62]. However, results of an in vitro study, conducted by Wang and DeVane [63], show neither the depletion of (R)- and (S)-methadone, nor the formation of EDDP by recombinant CYP1A2. Genetic variations in CYP1A2 did not affect or had little influence on the plasma concentrations of methadone and EDDP [22,46,59]. Additionally, Crettol et al. [64] 
observed $C Y P 1 A 2 * 1 F$ did not influence (R)-, (S)-, or (R,S)-methadone at the peak or trough levels in 245 MMT patients (96\% white) (Table 1). Based on the current studies, CYP1A2 SNPs have not been shown to impact the metabolism of methadone.

\subsection{CYP2 family}

The CYP2 family represents about $30 \%$ of human CYP isoforms, making it the largest CYP family $[65,66]$. The liver is comprised of five drug metabolizing CYP2 subfamilies (A-E), of which, the most pharmacologically important genes display the highest levels of polymorphism [54,55]. Methadone is metabolized by several members of the CYP2 family: 2B6, 2C8, 2C9, 2C18, 2C19, and 2D6.

3.2.1. CYP2B-CYP2B6 has a 1-10\% contribution to the total hepatic CYP pool, accounting for the metabolism of about $7-8 \%$ of pharmaceutical drugs [54,59]. Despite this enzymes' relatively low involvement in drug metabolism, CYP2B6 is the predominant determinant involved in the N-demethylation of methadone and clearance. CYP2B6 also displays stereoselectivity towards (S)-methadone [46,67]. CYP2B6 is one of the most polymorphic genes, having 70 allelic variants and 38 protein variants, which affect catalytic activity, transcriptional regulation, and splicing. The variants also affect mRNA and protein expression, exhibiting nearly 300 fold interindividual variability [54,60,68-71].

CYP2B6 SNPs can alter the metabolic ratios of [methadone]/[EDDP]. A significant decrease in the metabolic ratio was observed in individuals carrying the $C Y P 2 B \sigma^{*} 2$ allele, suggesting a role in an increased rate of metabolism. The data should be interpreted with caution because the subjects heterozygous for the variant only had a sample size of two [72]. A bioinformatics study also predicted $C Y P 2 B 6^{*} 2$ to alter the metabolic phenotype as determined by both the SIFT and PolyPhen algorithms [52].

Lee et al. [73] studied the influence of $C Y P 2 B 6^{*} 4$ on methadone plasma concentrations in 178 MMT patients in Taiwan. The study indicated an increase in $(\mathrm{R}, \mathrm{S})$-methadone plasma levels in individuals homozygous for $C Y P 2 B 6^{*} 4$. The results were consistent with the Levran et al. [74] study of 74 Israeli MMT patients; though neither study showed any significant differences in the increase in (R,S)-methadone plasma levels. On the other hand, Kharasch et al. [75] observed CYP2B6*4 carriers had a significant decrease in (R)-, (S)-, and $(\mathrm{R}, \mathrm{S})$-methadone plasma levels, with increased methadone metabolism and clearance. It is important to note that one of the limitations to this study was the small sample size ( $\mathrm{n}=$ 4). Gadel and colleagues [76] demonstrated an increase in N-demethylation of methadone by CYP2B6*4 in an in vitro study, supporting the findings of Kharasch et al. [75].

CYP2B $6^{*} 5$ shows contradicting data in its involvement in methadone clearance and plasma concentrations. In a genotyping study of methadone-only overdoses in 125 Caucasians, $C Y P 2 B 6^{*} 5$ was linked to a significant increase in (R,S)-methadone plasma levels [72]. In a study cohort consisting of 35 individuals with low (S)-methadone levels, $C Y P 2 B 6^{*} 5$ was over-represented, indicating an increased CYP2B6 activity [32]. The methadone plasma concentration of two individuals genotyped for homozygosity in $C Y P 2 B 6^{*} 5$ appeared to remain unaltered when compared to that of the wild type $C Y P 2 B 6^{*} 1$ [75]. 
$C Y P 2 B 6^{*} 6$ is a haplotype consisting of two nonsynonymous variants, $C Y P 2 B 6^{*} 4$ and $C Y P 2 B 6^{*} 9$. Numerous papers indicate an increase in $(\mathrm{R}, \mathrm{S})$ - and (S)-methadone plasma levels in $C Y P 2 B 6^{*} 6 / * 6$ individuals [64,67,75,77,78]. Gadel et al. [79] and Kharasch et al. [75] have also demonstrated a decrease in methadone N-demethylation and decreased methadone clearance, respectively. An in vitro study found SNPs $C Y P 2 B 6^{*} 6$ and $C Y P 2 B 6^{*} 9$ to be catalytically deficient in EDDP formation [76]. Furthermore, increased $(\mathrm{R}, \mathrm{S})$-methadone plasma levels were observed in 74 Israeli MMT patients homozygous for the $C Y P 2 B 6^{*} 9 \mathrm{SNP}$, though the increase was not statistically significant [74]. A significant increase in plasma concentrations and a decrease in (S)-methadone metabolism was observed in 366 Taiwanese MMT patients encompassing the $C Y P 2 B 6^{* 9} S N P$ [80]. The studies observing the SNPs of the haplotype $C Y P 2 B 6^{*} 6$ suggest that the diminishing metabolic activity of CYP2B6*6/*6 is credited to the c.516G > T variant of $C Y P 2 B 6^{*}$.

Dobrinas et al. [32] observed an overrepresentation of $C Y P 2 B 6^{*} 11$ polymorphism in a high (S)-methadone level group of MMT patients, indicating a decline in CYP2B6 activity. Wang et al. [80] examined polymorphisms in the intronic and $3^{\prime}$-untranslated region (UTR) regions of CYP2B6, and demonstrated the SNPs rs707265, rs2279345, rs1038376, and rs10403955 all correspond to increased [(S)-methadone/methadone dose] plasma ratios, and decreased (S)-methadone clearance (Table 1). The SNPs investigated in this section, demonstrate a compelling link to the importance of genetic variations in CYP2B6 and altered metabolism of methadone.

3.2.2. CYP2C-The CYP2C subfamily consists of four genes, $C Y P 2 C 8,2 C 9,2 C 18$, and 2C19. The CYPs from these genes all contribute to the metabolism of methadone $[46,77,81,82]$. CYP2C9 is the highest expressed isozyme of the four in liver, while CYP2C8 and CYP2C19 are expressed at 2 and 10 fold lower levels than CYP2C9 [54]. CYP2C18 is expressed primarily in the skin [59]. CYP2C19 comprises $16 \%$ of the CYP2C family and metabolizes methadone to a greater extent, as compared to the $\mathrm{CYP} 2 \mathrm{C} 8,2 \mathrm{C} 9$, and $2 \mathrm{C} 18$ isozymes [43]. The CYP2C family demonstrates stereoselectivity in methadone metabolism, where CYP2C8 and 2C19 predominately metabolize (R)-methadone, while CYP2C18 primarily metabolizes (S)-methadone.

Currently, there are no polymorphic studies on $C Y P 2 C 8$ and $2 C 18$ and their role in methadone metabolism. This is not surprising for $C Y P 2 C 18$, where only 8 variants have been reported to date $[60,83]$. There are 97 genetic variants observed in $C Y P 2 C 8[60,84]$, which has a minor role in the metabolism of methadone, probably contributing to the dearth of studies in the corresponding SNPs.

Although $C Y P 2 C 9$ exhibits 298 genetic variants and $2 C 19$ has 111 reported genetic variants $[60,85]$, only $* 2$ and $* 3$ have been examined for their respective CYP isozymes. Results from three separate studies showed no effect on methadone plasma levels with $C Y P 2 C 9 * 2$ and $C Y P 2 C 9 * 3$ genotypes in Caucasians $[64,77,82]$. A significant increase in methadone serum concentrations/dose ratio with heterozygous carriers of $C Y P 2 C 9 * 2$ and $C Y P 2 C 9 * 3$ SNPs was observed in a study in Norway. Similar results were seen for the homozygous $C Y P 2 C 9 * 2$ and $C Y P 2 C 9 * 3$ individuals, albeit, there was no significant differences in methadone serum concentrations/dose ratios [78]. 
In studies by Crettol et al. [64,77], $C Y P 2 C 19 * 2$ and $C Y P 2 C 19 * 3$ were also found to lack an effect on methadone plasma levels. A study of 366 Taiwanese MMT patients showed homozygous carriers of $C Y P 2 C 19 * 2$ were associated with a significant increase in (R)methadone levels. Patients homozygous for $C Y P 2 C 19 * 3$ also tended to exhibit an increase in (R)-methadone levels, although the data was not significantly different [86]. Carlquist et al. [87] observed an increase in the plasma levels of EDDP with $C Y P 2 C 19 * 2$ in 25 MMT patients (20 Caucasian, 4 Hispanic, and 1 African American), indicating an increase in methadone metabolism. Kringen et al. [78] noticed, in a Norwegian population, individuals homozygous and heterozygous carriers for $C Y P 2 C 19 * 2$ and $C Y P 2 C 19 * 3$ had an increase in methadone serum concentration/dose ratio, with significant differences seen only in heterozygotes. The contradicting results in the CYP2C19 variants between these studies could be attributed to the ethnicity of the patients, where the frequencies of both CYP2C19*2 and CYP2C19*3 are higher in Asians than Caucasians (Table 1).

3.2.3. CYP2D-The CYP2D subfamily consists of only one protein coding gene, CYP2D6, which accounts for $2-5 \%$ of the hepatic CYP composition and $~ 25 \%$ of pharmacological drug metabolism [54,88]. CYP2D6 metabolizes both enantiomers of methadone, with a slightly greater propensity towards (S)-methadone [46,63]. Unlike SNPs in other CYP genes, CYP2D6 phenotype is determined by allele combinations. PMs consist of two non-functional alleles, IMs are comprised of two decreased activity alleles, EMs have at least one functional allele, and UMs encompass more than one functional allele and/or an allele with a promoter mutation [82]. The major and most common mutation alleles are CYP2D $6 * 3, * 4, * 5$, and $* 6$, accounting for $93-97 \%$ of alleles among PM phenotypes [89,90]. $C Y P 2 D 6^{*} 1$ and $C Y P 2 D 6^{*} 2$ alleles represent normal functional activity.

In a 2001 study conducted by Eap et al. [89], CYP2D6 phenotypes had a significant influence on the (R)-, (S)-, and (R,S)-methadone blood concentrations, where higher concentrations were observed in PMs $\left(C Y P 2 D 6^{*} 4 / * 4, * 4 * 3, * 4 / * 6\right)$ and lower concentrations were measured in UMs $\left.\left(C Y P 2 D 6^{*} 1\right)^{*} 1\right)$. Similarly, Crettol and colleagues [64], observed a 0.5 fold decrease in (S)-methadone and 0.7 fold decrease in (R)-methadone plasma levels in UMs $\left(C Y P 2 D 6^{*} 11^{*} 1 x N\right)$ when compared to the EM/IM $\left(C Y P 2 D 6^{*} 1\right)^{*} 3$, $* 1 / * 4, * 1 / * 5, * 1 / * 6$ ) group. In another study, the PM, IM, and EM phenotypes, representing alleles $C Y P 2 D 6^{*} 1, * 1 x N, * 2, * 3, * 4, * 4 x N, * 5, * 6, * 9, * 10, * 16, * 28, * 33$, and $* 41$, did not impact the clearance of (R)-, (S)-, or (R,S)-methadone [91]. CYP2D6*3,*4,*5,*6,*7, and $* 8$ are non-functional variants, and $C Y P 2 D 6^{*} 9, * 10$, and $* 41$ have a decrease in function [91]. Fonseca et al. [82] observed EM patients received significantly lower doses of methadone as compared to UMs. It was also concluded that, contradictory to the phenotypes, UM $\left(C Y P 2 D 6^{*} 1 x N, * 2 x N\right)$ patients had significantly higher methadone plasma levels than EM $\left(C Y P 2 D 6^{*} 1, * 2, * 3, * 6, * 35\right)$ and PM $\left(C Y P 2 D 6^{*} 4{ }^{*} 4\right)$ patients. Further investigations on the $C Y P 2 D 6$ alleles need to be conducted to get a clearer understanding of their significance. The relationship between $C Y P 2 D 6$ allelic variants and phenotypic expression is depicted in Table 2. 


\subsection{CYP3 family}

The CYP3 family consists of only one subfamily, CYP3A, and four functional genes, $C Y P 3 A 4,3 A 5,3 A 7$, and $3 A 43$. These enzymes play a dominant role in drug metabolism pathways $(\sim 50 \%)$. CYP3A4 is the most expressed enzyme in adult liver, while CYP3A7 is predominantly expressed in fetal liver and is down-regulated after birth. CYP3A5 is polymorphically expressed in the liver, where alternative splicing results in multiple transcript variants, exhibiting high and low level proteins [54,88,92].

Methadone has been shown to be N-demethylated by CYP3A4, 3A5, and 3A7 in a nonstereoselective manner [46,93]. $C Y P 3 A 4$ and $C Y P 3 A 5$ have relatively low numbers of genetic variants, suggesting minor clinical importance in the clearance of their respective substrates $[59,74]$. This observation would be in line with the lack of polymorphic studies found for CYP3A and their role in methadone metabolism. However, in one study, the allelic frequency of $C Y P 3 A 4 * 1 B$ in 245 MMT patients (96\% white) was observed and correlated with an increase in methadone plasma levels [64]. In the same study, the study cohort was genotyped for the deficient allele $C Y P 3 A 5^{*} 3$. The plasma levels of methadone were not influenced by the $C Y P 3 A 5$ genotype. It is also interesting to note that there was a strong linkage between $C Y P 3 A 4 * 1 B$ and $C Y P 3 A 5 * 3$ genotypes [64]. Similar results were observed by Fonseca et al. [82], where the genetic polymorphism of $C Y P 3 A 5$ did not influence methadone plasma levels. One case report of a 25-year old male in a MMT program showed extensive metabolism of methadone to EDDP. The subject was found to be heterozygous for $C Y P 3 A 5^{*} 1\left(C Y P 3 A 5^{*} 1 / * 3\right)$ [94]. A large amount of CYP3A5 is expressed in individuals carrying at least one $C Y P 3 A 5^{*} 1$ allele [94]. In a recent study of 155 serum samples and 62 patients, homozygous carriers of $C Y P 3 A 5 * 3$ demonstrated a significant increase in methadone serum concentration/dose ratio, indicating a decrease in methadone clearance [78] (Table 1).

\section{Consequences of altered methadone metabolism}

Polymorphisms in genes encoding CYP enzymes have the potential to shift their metabolic capacity or change the substrate specificity of the enzyme, eliciting variable consequences in drug treatment $[95,96]$. These changes can be crucial in the therapeutic potency of methadone. The main metabolic pathway of methadone involves the N-demethylation by hepatic CYPs into the primary metabolite, EDDP. Changes in the rate of EDDP formation could influence the pharmacodynamics of methadone.

$C Y P 2 B 6^{*} 4$ was the only SNP that was found to increase the clearance of methadone by the $\mathrm{N}$-demethylation of both $(\mathrm{R})$ - and $(\mathrm{S})$-methadone [75,76]. In turn, there would be a decrease in the disposition of $(\mathrm{R}, \mathrm{S})$-methadone, reducing the pharmacological effect of methadone and inducing withdrawal symptoms. Individuals with this SNP may require a higher dose of methadone.

Several SNPs were found to increase the methadone plasma concentration due to a decrease in the metabolic activity of the CYPs. Three independent studies collectively demonstrated elevated plasma levels of (R,S)- and (S)-methadone with diminishing N-demethylation of (R)- and (S)-methadone due to $C Y P 2 B 6^{*} 2$, ${ }^{*} 9$ and $* 11[32,72,74,76,80] . C Y P 2 B 6^{*} 6$ is a 
haplotype consisting of both $C Y P 2 B 6^{*} 4$ and $C Y P 2 B 6^{*} 9$ variants. Carriers of $C Y P 2 B 6^{*} 6 / * 6$ had diminished methadone metabolism and clearance, hence, an increase in methadone levels. This activity is credited to the $C Y P 2 B 6^{*} 9 \mathrm{SNP}$, where individuals with $C Y P 2 B 6^{*} 4 / * 6$ haplotype did not observe the metabolic inhibition [64,67,75-79]. Mutations located in the UTR and intronic regions are also relevant in the biotransformation of methadone. Table 1 shows the four SNPs in the UTR and intronic regions linked to a decreased clearance and increased concentration of methadone [80]. CYP2B6 influences the metabolism of (S)-methadone and, to a far lesser extent,(R)-methadone. Individuals with the genotypes mentioned above, particularly $C Y P 2 B 6^{*} 6 / * 6$, have a greater risk of suffering torsades de pointes and sudden death. A lower dose of methadone may be required for treatment for individuals with these variants.

Reduced metabolism by CYP2C19 can lead to increased plasma concentrations of methadone, specifically (R)-methadone, which can potentiate depressed ventilation manifesting as a potentially fatal respiratory depression. Both $C Y P 2 C 19 * 2$ and $C Y P 2 C 19 * 3$ were associated with elevated methadone plasma concentrations $[78,86]$. However, these results could be variable in different ethnic groups.

CYP2D6 and CYP3A4/5 metabolize both enantiomers of methadone, though CYP2D6 has a slightly greater preference towards (S)-methadone. Decreased metabolism by these CYPs may heighten either detrimental effect due to augmented levels of methadone. $C Y P 3 A 4^{*} 1 B$ has been shown to increase (S)-methadone plasma levels [64], which can lead to cardiotoxic effects. In a study of 136 Caucasian individuals who died of methadone-only overdosing, an enrichment was observed in the $C Y P 3 A 4 * 1 B S N P$ [97]. CYP3A5*3 is a common SNP with high frequency in the Caucasian population, where a splicing defect causes a loss of function of the $C Y P 3 A 5$ enzyme [58]. This is exemplified in a couple of studies where the methadone plasma levels are elevated in $C Y P 3 A 5^{*} 3 / * 3$ individuals, while metabolism is increased and plasma levels are decreased in individuals carrying at least one copy of $C Y P 3 A 5^{*} 1[79,94]$. The effects of SNPs located on the CYP2D6 gene is slightly more complicated. CYP2D6-dependent metabolism of methadone has been studied based on the phenotypic variability determined by a combination of SNPs on the CYP2D6 gene. There have not been any clear implications on the relationship between CYP2D6 SNPs and methadone metabolism and their role on the pharmacokinetics and pharmacodynamics of methadone.

Since methadone is metabolized by a number of CYPs, a combination of any of the SNPs, within or between genes, can have varying effects on the pharmacological response of methadone treatment. A genome-wide pharmacogenomic study showed two CYP2B6 haplotypes of rs8100458, rs7250601, rs7250991, rs11882424, rs8192719, and rs10853744 (T-A-A-T-C-G and T-C-C-T-T-T) accounted for the variation in (S)-methadone plasma levels [98]. In order to understand the complexity of the effects of CYP SNPs on methadone pharmacokinetics and pharmacodynamics, inclusion of additional gene variants and haplotype variants is required. Though SNPs influence only part of methadone pharmacology, the impact of genetic variations can be compounded by drug interactions, environmental factors, sex, health, and other nongenetic factors. Co-administration of methadone with respiratory depressants, such as other opioids, alcohol, or benzodiaze-pines, may lead to a greater 
detrimental effect. Likewise, individuals with reduced liver function (e.g. cirrhosis) could have a reduced capacity to metabolize methadone.

\section{Conclusion}

Methadone is currently used as a treatment and maintenance therapy for opioid addiction and as an analgesic for severe chronic pain. The wide-ranging half-life of methadone may result in some individuals having higher than normal therapeutic levels leading to negative, detrimental, and fatal side effects. Elevated (R)-methadone levels may lead to respiratory depression, while an increase in plasma levels of (S)-methadone may lead to severe cardiac arrhythmias. A significant portion of opioid-related deaths have been contributed to the use of prescription methadone for pain management. The pharmacogenetics of an individual possesses the ability to affect the pharmacokinetics and pharmacodynamics of methadone. SNPs located on CYP genes shift the metabolic capacity or change the substrate specificity of the CYP enzyme, affecting the metabolism of methadone. SNPs $C Y P 2 B 6 * 6, * 9, * 11$, $C Y P 2 C 19 * 2, * 3, C Y P 3 A 4 * 1 B$, and $C Y P 3 A 5^{*} 3$ result in increased methadone plasma concentrations, decreased N-demethylation, and decreased methadone clearance. Since CYP2B6 is the major determinant of methadone clearance, $C Y P 2 B 6^{*} 6 /{ }^{*} 6$ is of particular interest. Homozygous carriers of $C Y P 2 B 6^{*} 6 /{ }^{*} 6$ expressed diminished methadone metabolism and clearance, thus these individuals have a greater propensity for detrimental adverse effects. However, $C Y P 2 B 6^{*} 4$ demonstrated an increase in N-demethylation and methadone clearance. A better understanding of the role of CYP SNPs in methadone metabolism can improve the proper therapeutic dosing for methadone, patient outcome, and the development of individualized medicine.

\section{Abbreviations:}

$\begin{array}{ll}\text { ADH } & \text { alcohol dehydrogenase } \\ \text { CDC } & \text { Centers for Disease Control and Prevention } \\ \text { CYP } & \text { cytochrome P450 } \\ \text { Del } & \text { deletion } \\ \text { EDDP } & \text { 2-ethyl-1,5-dimethyl-3,3-diphenylpyrrolidine } \\ \text { EM } & \text { extensive metabolizer } \\ \text { EMDP } & \text { 2-ethyl-5-methyl-3,3-diphenyl-1-pyrroline } \\ \text { FDA } & \text { Food and Drug Administration } \\ \text { hERG } & \text { human ether-a-go-go related gene } \\ \text { IM } & \text { intermediate metabolizer } \\ \text { MMT } & \text { methadone maintenance treatment } \\ \text { MOR } & \mu \text {-opioid receptor }\end{array}$




$\begin{array}{ll}\text { MTD } & \text { methadone } \\ \text { NCBI } & \text { National Center for Biotechnology Information } \\ \boldsymbol{p} \text {-HO } & \text { para-hydroxy } \\ \text { PM } & \text { poor metabolizer } \\ \text { SNP } & \text { single nucleotide polymorphism } \\ \text { UM } & \text { ultra-rapid metabolizer } \\ \text { UTR } & \text { untranslated region }\end{array}$

\section{References}

[1]. Rettig R, Yarmolinsky A, Executive Summary. Institute of Medicine, Federal Regulation of Methadone Treatment, The National Academies Press, Washington, DC, 1995, p. 1,, http:// dx.doi.org/10.17226/4899.

[2]. Dole VP, Nyswander M, A medical treatment for diacetylmorphine (heroin) addiction. A clinical trial with methadone hydrochloride, JAMA 23 (1965) 646-650, 10.1001/jama. 1965.03090080008002.

[3]. Joseph H, Stancliff S, Langord J, Methadone maintenance treatment (MMT): a review of historical and clinical issues, Mt Sinai J. Med 67 (2000) 347-364. [PubMed: 11064485]

[4]. Drucker E, Lurie P, Wodakt A, Alcabes P, Measuring harm reduction: the effects of needle and syringe exchange programs and methadone maintenance on the ecology of HIV, AIDS 12 (Suppl. A) (1998) S217-S230. [PubMed: 9633006]

[5]. Somogyi AA, Barratt DT, Ali RL, Coller JK, Pharmacogenomics of methadone maintenance treatment, Pharmacogenomics 15 (2014) 1007-1027, 10.2217/pgs.14.56. [PubMed: 24956254]

[6]. Anderson IB, Kearney TE, Use of methadone, West J. Med 172 (2000) 43-46, 10.1136/ewjm. 172.1.43. [PubMed: 10695444]

[7]. Lisberg P, Scheinmann F, Is it time to consider use of levomethadone (R-(-)-methadone) to replace racemic methadone? J. Develop Drugs 2 (2013) 109, 10.4172/2329-6631.1000109.

[8]. Langrod J, Lowinson J, Ruiz P, Methadone treatment and physical complaints: a clinical analysis, Int. J. Addict 16 (1981) 947-952, 10.3109/10826088109038903. [PubMed: 7199031]

[9]. Reisine T, Law SF, Blake A, Tallent M, Molecular mechanism of opiate receptor coupling to G proteins and effector systems, Ann. New York Acad. Sci 780 (1996) 168-175, 10.1111/j. 1749-6632.1996.tb15121.x. [PubMed: 8602730]

[10]. Li Y, Kantelip JP, Gerritsen-van Schieveen P, Davani S, Interindividual variability of methadone response: impact of genetic polymorphism, Mol. Diagn. Ther 12 (2008) 109-124, 10.1007/ BF03256276. [PubMed: 18422375]

[11]. Methadose ${ }^{\mathrm{TM}}$ Oral Concentrate (methadone hydrochloride oral concentrate USP) and Methadose $^{\text {TM }}$ Sugar-Free Oral Concentrate (methadone hydrochloride oral concentrate USP) dyefree, sugar-free, unflavored [package insert] Mallinckrodt Pharmaceuticals, Inc., Hazelwood, MO, 2016 < https://www.accessdata.fda.gov/drugsatfda_docs/label/2016/017116s029lbl.pdf. Accessed Nov 3, $2017>$.

[12]. Gaertner J, Volts R, Ostgathe C, Methadone: a closer look at the controversy, J. Pain Symptom Manage. 36 (2008) e4-e7, 10.1016/j.jpainsymman.2008.04.007.

[13]. Kapur BM, Hutson JR, Chibber T, Luk A, Selby P, Methadone: a review of drug-drug and pathophysiological interactions, Crit. Rev. Clin. Lab. Sci 48 (2011) 171-195, 10.3109/10408363.2011.620601. [PubMed: 22035341]

[14]. McCance-Katz EF, (R)-methadone versus racemic methadone: what is best for patient care? Addiction 106 (2011) 687-688, 10.1111/j.1360-0443.2011.03374.x. [PubMed: 21371149] 
[15]. Stotts AL, Dodrill CL, Kosten TR, Opioid dependence treatment: options in pharmacotherapy, Expert Opin. Pharmacother 10 (2009) 1727-1740, 10.1517/14656560903037168. [PubMed: 19538000]

[16]. Bart G, Maintenance medication for opiate addiction: the foundation of recovery, J. Addict. Dis 31 (2012) 207-225, 10.1080/10550887.2012.694598. [PubMed: 22873183]

[17]. Kreek MJ, Levran O, Reed B, Schlussman SD, Zhou Y, Butelman ER, Opiate addiction and cocaine addiction: underlying molecular neurobiology and genetics, J. Clin. Invest 122 (2012) 3387-3393, 10.1172/JCI60390. [PubMed: 23023708]

[18]. Peles E, Linzy S, Kreek MJ, Adelson M, Prospective study of QTc changes among former opiate addicts since admission to methadone maintenance treatment: benzodiazepine risk, J. Addict. Med 7 (2013) 428-434, 10.1097/ADM.0b013e3182a8a4f2 [PubMed: 24145160]

[19]. McDonough M, Opioid treatment of opioid addiction, Aust. Prescr 36 (2013) 83-87, http:// dx.doi.org/10.18773/austprescr.2013.033.

[20]. Taylor WF, Finkel AG, Robertson KR, Anderson AC, Toomey TC, Abashian SA, Mann JD, Methadone in the treatment of chronic nonmalignant pain: a 2-year follow-up, Pain Med 1 (2000) 254-259, 10.1046/j.1526-4637.2000.00027.x. [PubMed: 15101892]

[21]. Toombs JD, Kral LA, Methadone treatment for pain states, Am. Fam. Physician 71 (2005) 13531358. [PubMed: 15832538]

[22]. Fredheim OMS, Oksnes KM, Orchgrevink PCB, Aasa SK, Dale O, Clinical pharmacology of methadone for pain, Acta Anaesthesiol. Scand 52 (2008) 879-889, 10.1111/j. 1399-6576.2008.01597.x.

[23]. Jackman RP, Purvis JM, Chronic nonmalignant pain in primary care, Am. Fam. Physician 78 (2008) 1155-1162. [PubMed: 19035063]

[24]. Kahan M, Srivastava A, Wilson L, Mailis-Gagnon A, Midner D, Opioids for managing chronic non-malignant pain: safe and effective prescribing, Can. Fam. Physician 52 (2006) 1091-1096. [PubMed: 17279219]

[25]. Jones CM, Baldwin GT, Manocchio T, White JO, Mack KA, Trends in methadone distribution for pain treatment, methadone diversion, and overdose deaths - United States, 2002-2014, Morb. Mortal Wkly Rep 65 (2016) 667-671, http://dx.doi.org/10.15585/mmwr.mm6526a2.

[26]. Rudd RA, Aleshire N, Zibbell JE, Gladden RM, Increases in drug and opioid-involved overdose deaths —United States, 2010-2015, Morb. Mortal Wkly Rep 65 (2016) 1445-1452, http:// dx.doi.org/10.15585/mmwr.mm655051e1.

[27]. Mitchell TB, Dyer KR, Newcombe D, Salter A, Somogyi AA, Bochner F, White JM, Subjective and physiological responses among racemic-methadone maintenance patients in relation to relative (S)- vs. (R)-methadone exposure, Br. J. Clin. Pharmacol 58 (2004) 609-617, 10.1111/j. 1365-2125.2004.02221.x. [PubMed: 15563359]

[28]. Silverman DA, Nettleton RT, Spencer KB, Wallisch M, Olsen GD, S-Methadone augments Rmethadone induced respiratory depression in the neonatal guinea pig, Respir. Physiol. Neurobiol 169 (2009) 252-261, 10.1016/j.resp.2009.09.001. [PubMed: 19744579]

[29]. van der Schier R, Roozekrans M, van Velzen M, Dahan A, Niesters M, Opioid-induced respiratory depression: reversal by non-opioiddrugs, F1000Prime Rep 6 (2014) 79, http:// dx.doi.org/10.12703/P6-79. [PubMed: 25343036]

[30]. Eap CB, Crettol S, Rougier JS, Schlapfer J, Grilo LS, Deglon JJ, Besson J, Croquette-Krokar M, Carrupt PA, Abriel H, Stereoselective block of hERG channel by (S)-methadone and QT interval prolongation in CYP2B6 slow metabolizers, Clin. Pharmacol. Ther 81 (2007) 719-728, 10.1038/ sj.clpt.6100120. [PubMed: 17329992]

[31]. Ansermot N, Albayrak Ö, Schläpfer J, Crettol S, Croquette-Krokar M, Bourquin M, Déglon J, Faouzi M, Scherbaum N, Eap CB, Substitution of (R, S)-methadone by (R)-methadone impact on QT interval, Arch. Intern. Med 170 (2010) 529-536, 10.1001/archinternmed.2010.26. [PubMed: 20308640]

[32]. Dobrinas M, Crettol S, Oneda B, Lahyani R, Rotger M, Choong E, Lubomirov R, Csajka C, Eap $\mathrm{CB}$, Contribution of CYP2B6 alleles in explaining extreme (S)-methadone plasma levels: a CYP2B6 gene resequencing study, Pharmacogenet. Genomics 23 (2013) 84-93, 10.1097/FPC. 0b013e32835cb2e2. [PubMed: 23249875] 
[33]. Csajka C, Crettol S, Guidi M, Eap CB, Population genetic based pharmacokinetic modeling of methadone and its relationship with the QTc interval in opioid-dependent patients, Clin. Pharmacokinet 55 (2016) 1521-1533, 10.1007/s40262-016-0415-2. [PubMed: 27286724]

[34]. Moody DE, Alburges ME, Parker RJ, Collins JM, Strong JM, The involvement of cytochrome P450 3A4 in the N-demethylation of L-alpha-acetylmethadol (LAAM), norLAAM, and methadone, Drug Metab. Dispos 25 (1997) 1347-1353. [PubMed: 9394023]

[35]. Oda Y, Kharasch ED, Metabolism of methadone and levo-alpha-acetylmethadol (LAAM) by human intestinal cytochrome P450 3A4 (CYP3A4): potential contribution of intestinal metabolism to presystemic clearance and bioactivation, J. Pharmacol. Exp. Ther 298 (2001) 1021-1032. [PubMed: 11504799]

[36]. Ferrari A, Coccia CP, Bertolini A, Sternieri E, Methadone-metabolism, pharmacokinetics and interactions, Pharmacol. Res 50 (2004) 551-559, 10.1016/j.phrs.2004.05.002. [PubMed: 15501692]

[37]. Nanovskaya TN, Deshmukh SV, Nekhayeva IA, Zharikova OL, Hankins GD, Ahmed MS, Methadone metabolism by human placenta, Biochem. Pharmacol 68 (2004) 583-591, 10.1016/ j.bcp.2004.04.011. [PubMed: 15242824]

[38]. Lehotay DC, George S, Etter ML, Graybiel K, Eichhorst JC, Fern B, Wildenboer W, Selby P, Kapur B, Free and bound enantiomers of methadone and its metabolite, EDDP in methadone maintenance treatment: relationship to dosage? Clin. Biochem 12 (2005) 1008-1094, 10.1016/ j.clinbiochem.2005.09.009.

[39]. Lugo RA, Satterfield KL, Keru SE, Pharmacokinetics of methadone, J. PainPalliat Care Pharmacother 19 (2005) 13-24, 10.1080/J354v19n04_05.

[40]. Eap CB, Buclin T, Baumann P, Interindividual variability of the clinical pharmacokinetics of methadone: implications for the treatment of opioid dependence, Clin. Pharmacokinet 41 (2002) 1153-1193, 10.2165/00003088-200241140-00003. [PubMed: 12405865]

[41]. Daly AK, Pharmacogenetics of the Cytochromes P450, Curr. Top. Med. Chem 4 (2004) 17331744, 10.2174/1568026043387070. [PubMed: 15579105]

[42]. Smith HS, Opioid metabolism, Mayo Clin. Proc 84 (2009) 613-624, 10.4065/84.7.613. [PubMed: 19567715]

[43]. Dinis-Oliveira RJ, Metabolomics of methadone: clinical and forensic toxicological implications and variability of dose response, Drug Metab. Rev 48 (2016) 568-576, 10.1080/03602532.2016.1192642. [PubMed: 27320437]

[44]. Sullivan HR, Due SL, Urinary metabolites of dl-methadone in maintenance subjects, J. Med. Chem 16 (1973) 909-913, 10.1021/jm00266a009. [PubMed: 4745834]

[45]. Anggård E, Gunne LM, Homstrand J, McMahon RE, Sandberg CG, Sullivan HR, Disposition of methadone in methadone maintenance, Clin. Pharmacol. Ther 17 (1975) 258-266, 10.1002/ cpt1975173258. [PubMed: 1120392]

[46]. Chang Y, Fang WB, Lin SN, Moody DE, Stereo-selective metabolism of methadone by human liver microsomes and cDNA-expressed cytochrome P450s: a reconciliation, Basic Clin. Pharmacol. Toxicol 108 (2011) 55-62, 10.1111/j.1742-7843.2010.00628.x. [PubMed: 20825389]

[47]. Lemke TL, Williams DA, Roche VF, Zito SW, Chapter 20/Central Analgesics, Foye's Principles of Medicinal Chemistry, 7th ed, Lippincott Williams \& Wilkins, 2013, pp. 686-687.

[48]. DePriest AZ, Puet BL, Holt AC, Roberts A, Cone EJ, Metabolism and disposition of prescription opioids: a review, Forensic Sci. Rev 27 (2015) 115-145. [PubMed: 26227254]

[49]. Boulton DW, Arnaud P, DeVane CL, Pharmacokinetics and pharmacodynamics of methadone enantiomers after a single oral dose of racemate, Clin. Pharmacol. Ther 70 (2001) 48-57, 10.1067/mcp.2001.116793. [PubMed: 11452244]

[50]. Leshner AI, Drug abuse and addiction treatment research. The next generation, Arch. Gen. Psychiatry 54 (1997) 691-694, 10.1001/archpsyc.1997.01830200015002. [PubMed: 9283502]

[51]. Kristensen K, Blemmer T, Angelo HR, Christrup LL, Drenck NE, Rasmussen SN, Sjøgren P, Stereoselective pharmacokinetics of methadone in chronic pain patients, Ther. Drug Monit 18 (1996) 221-227, 10.1097/00007691-199606000-00001. [PubMed: 8738759] 
[52]. Wang LL, Li Y, Zhou SF, A bioinformatics approach for the phenotype prediction of nonsynonymous single nucleotide polymorphisms in human cytochromes P450, Drug Metab. Dispos 37 (2009) 977-991, 10.1124/dmd.108.026047. [PubMed: 19204079]

[53]. Wang H, Tompkins LM, CYP2B6: new insights into a historically overlooked cytochrome P450 isozyme, Curr. Drug Metab 9 (2008) 598-610, 10.2174/138920008785821710. [PubMed: 18781911]

[54]. Zanger UM, Schwab M, Cytochrome P450 enzymes in drug metabolism: regulation of gene expression, enzyme activities, and impact of genetic variation, Pharmacol. Ther 138 (2013) $103-$ 141, 10.1016/j.pharmthera.2012.12.007. [PubMed: 23333322]

[55]. Solus JF, Arietta BJ, Harris JR, Sexton DP, Steward JQ, McMunn C, Ihrie P, Mehall JM, Edwards TL, Dawson EP, Genetic variation in eleven phase I drug metabolism genes in an ethnically diverse population, Pharmacogenomics 5 (2004) 895-931, 10.1517/14622416.5.7.895. [PubMed: 15469410]

[56]. Sadee W, Wang D, Papp AC, Pinsonneault JK, Smith RM, Moyer RA, Johnson AD, Pharmacogenomics of the RNA world: structural RNA polymorphisms in drug therapy, Clin. Pharmacol. Ther 89 (2011) 355-365, 10.1038/clpt.2010.314. [PubMed: 21289622]

[57]. Johansson I, Ingelman-Sundberg M, CNVs of human genes and their implication in pharmacogenetics, Cytogenet. Genome Res 123 (2008) 195-204, 10.1159/000184709. [PubMed: 19287156]

[58]. McGraw J, Waller D, Cytochrome P450 variations in different ethnic populations, Expert Opin. Drug Metab. Toxicol 8 (2012) 371-382, 10.1517/17425255.2012.657626. [PubMed: 22288606]

[59]. Zhou SF, Liu JP, Chowbay B, Polymorphism of human cytochrome P450 enzymes and its clinical impact, Drug Metab. Rev 41 (2009) 89-285, 10.1080/03602530902843483. [PubMed: 19514967]

[60]. Fokkema IF, Taschner PE, Schaafsma GC, Celli J, Laros JF, den Dunnen JT, LOVD v. 2.0: the next generation in gene variant databases, Hum. Mutat 32 (2011) 557-563, 10.1002/humu.21438. [PubMed: 21520333]

[61]. Fokkema IF, den Dunnen JT, CYP1A2 gene homepage. Available from: <https://www.LOVD.nl// CYP1A2 2017 > (accessed 21.11.2017).

[62]. Zhou SF, Polymorphism of human cytochrome P450 2D6 and its clinical significance: part II, Clin. Pharmacokinet 48 (2009) 761-804, 10.2165/11318070-000000000-00000. [PubMed: 19902987]

[63]. Wang JS, DeVane CL, Involvement of CYP3A4, CYP2C8, and CYP2D6 in the metabolism of (R)- and (S)-methadone in vitro, Drug Metab. Dispos 31 (2003) 742-747, 10.1124/dmd.31.6.742. [PubMed: 12756206]

[64]. Crettol S, Déglon JJ, Besson J, Croquette-Krokar M, Hämmig R, Gothuey I, Monnat M, Eap CB, $\mathrm{ABCB} 1$ and cytochrome P450 genotypes and phenotypes: influence on methadone plasma levels and response to treatment, Clin. Pharmacol. Ther 80 (2006) 668-681, 10.1016/j.clpt.2006.09.012. [PubMed: 17178267]

[65]. Kim JH, Cheong HS, Park BL, Kim LH, Shin HJ, Na HS, Chung MW, Shin HD, Direct sequencing and comprehensive screening of genetic polymorphisms on CYP2 family genes (CYP2A6, CYP2B6, CYP2C8, and CYP2E1) in five ethnic populations, Arch. Pharm. Res 38 (2015) 115-128, 10.1007/s12272-014-0348-y. [PubMed: 24988984]

[66]. Daly A, CYP2 family [Video file]. In: The Biomedical \& Life Sciences Collection, Henry Stewart Talks, 2016 Available from: < https://hstalks.com/bs/685/ > (accessed 21.11.2017).

[67]. Kharasch ED, Stubbert K, Role of cytochrome P4502B6 in methadone metabolism and clearance, J. Clin. Pharmacol 53 (2013) 305-313, 10.1002/jcph.1. [PubMed: 23361846]

[68]. Fokkema IF, den Dunnen JT, CYP2B6 gene homepage. Available from: <https://www.LOVD.nl/ CYP2B6 2017 > (accessed 21.11.2017).

[69]. Zhou Y, Ingelman-Sundberg M, Lauschke VM, Worldwide distribution of cyto-chrome P450 alleles: a meta-analysis of population-scale sequencing projects, Clin. Pharmacol. Ther 102 (2017) 688-700, 10.1002/cpt.690. [PubMed: 28378927] 
[70]. Ingelman-Sundberg M, Daly AK, Nebert DW, CYP2B6 allele nomenclature of the Human Cytochrome P450 (CYP) Allele Nomenclature Committee. Available from: < https:// www.pharmvar.org/htdocs/archive/index_original.htm > (accessed 21.11.2017).

[71]. Zanger UM, Klein K, Pharmacogenetics of cytochrome P450 2B6 (CYP2B6): advances on polymorphisms, mechanisms, and clinical relevance, Front. Genet 4 (2013) 24, 10.3389/fgene. 2013.00024. [PubMed: 23467454]

[72]. Ahmad T, Sabet S, Primerano DA, Richards-Waugh LL, Rankin GO, Tell-tale SNPs: the role of CYP2B6 in methadone fatalities, J. Anal. Toxicol 41 (2017) 325-333, 10.1093/jat/bkw135. [PubMed: 28184434]

[73]. Lee HY, Li JH, Sheu YL, Tang HP, Chang WC, Tang TC, Yeh YC, Wang SY, Liu RH, Moving toward personalized medicine in the methadone maintenance treatment program: a pilot study on the evaluation of treatment responses in Taiwan, Biomed. Res. Int 2013 (2013) 741403, 10.1155/2013/741403. [PubMed: 24455721]

[74]. Levran O, Peles E, Hamon S, Randesi M, Adelson M, Kreek MJ, CYP2B6 SNPs are associated with methadone dose required for effective treatment of opioid addiction, Addict. Biol 18 (2013) 709-716, 10.1111/j.1369-1600.2011.00349.x. [PubMed: 21790905]

[75]. Kharasch ED, Regina KJ, Blood J, Friedel C, Methadone pharmacogenetics: CYP2B6 polymorphisms determine plasma concentrations, clearance, and metabolism, Anesthesiology 123 (2015) 1142-1153, 10.1097/ALN.0000000000000867. [PubMed: 26389554]

[76]. Gadel S, Friedel C, Kharasch ED, Differences in methadone metabolism by CYP2B6 variants, Drug Metab. Dispos 43 (2015) 994-1001, 10.1124/dmd.115.064352. [PubMed: 25897175]

[77]. Crettol S, Déglon JJ, Besson J, Croquette-Krokkar M, Gothuey I, Hämmig R, Monnat M, Hüttemann H, Baumann P, Eap CB, Methadone enantiomer plasma levels, CYP2B6, CYP2C19, and CYP2C9 genotypes, and response to treatment, Clin. Pharmacol. Ther 78 (2005) 593-604, 10.1016/j.clpt.2005.08.011. [PubMed: 16338275]

[78]. Kringen MK, Chalabianloo F, Bernard JP, Bramness JG, Molden E, Høiseth G, Combined effect of CYP2B6 genotype and other candidate genes on a steady-state serum concentration of methadone in opioid maintenance treatment, Ther. Drug Monit 39 (2017) 550-555, 10.1097/ FTD.0000000000000437. [PubMed: 28723731]

[79]. Gadel S, Crafford A, Regina K, Kharasch ED, Methadone N-demethylation by the common CYP2B6 allelic variant CYP2B6.6, Drug Metab. Dispos 41 (2013) 709-713, 10.1124/dmd. 112.050625. [PubMed: 23298862]

[80]. Wang SC, Ho IK, Tsou HH, Tian JN, Hsiao CF, Chen CH, Tan HK, Lin L, Wu CS, Su LW, Huang CL, Yang YH, Liu ML, Lin KM, Chen CY, Liu SC, Wu HY, Chan HW, Tsai MH, Lin PS, Liu YL, CYP2B6 polymorphisms influence the plasma concentration and clearance of the methadone S-enantiomer, J. Clin. Psychopharmacol 31 (2011) 463-469, 10.1097/JCP. 0b013e318222b5dd. [PubMed: 21694616]

[81]. Iribarne C, Berthou F, Baird S, Dréano Y, Picart D, Bail JP, Beaune P, Ménez JF, Involvement of cytochrome P450 3A4 enzyme in the N-demethylation of methadone in human liver microsomes, Chem. Res. Toxicol 9 (1996) 365-373, 10.1021/tx950116m. [PubMed: 8839037]

[82]. Fonseca F, de la Torre R, Díaz L, Pastor A, Cuyàs E, Pizarro N, Khymenets O, Farré M, Torrens $\mathrm{M}$, Contribution of cytochrome $\mathrm{P} 450$ and $\mathrm{ABCB} 1$ genetic variability on methadone pharmacokinetics, dose requirements, and response, PLoS One 6 (2011) e19527, 10.1371/ journal.pone.0019527. [PubMed: 21589866]

[83]. Fokkema IF, den Dunnen JT, CYP2C18 gene homepage, 2017 Available from: < https:// www.LOVD.n1//CYP2C18 > (accessed 21.11.2017).

[84]. Fokkema IF, den Dunnen JT, CYP2C8 gene homepage, 2017 Available from: < https:// www.LOVD.nl//CYP2C8 > (accessed 21.11.2017).

[85]. Fokkema IF, den Dunnen JT, CYP2C19 gene homepage, 2017 Available from: < https:// www.LOVD.nl//CYP2C19 > (accessed 21.11.2017).

[86]. Wang SC, Ho IK, Tsou HH, Liu SW, Hsiao CF, Chen CH, Tan HK, Lin L, Wu CS, Su LW, Huang CL, Yang YH, Liu ML, Lin KM, Liu SC, Wu HY, Kuo HW, Chen AC, Chang YS, Liu YL, Functional genetic polymorphisms in CYP2C19 gene in relation to cardiac side effects and 
treatment dose in a methadone maintenance cohort, OMICS 17 (2013) 519-526, 10.1089/omi. 2012.0068. [PubMed: 24016178]

[87]. Carlquist JF, Moody DE, Knight S, Johnson EG, Fang WB, Huntinghouse JA, Rollo JS, Webster LR, Anderson JL, A possible mechanistic link between the CYP2C19 genotype, the methadone metabolite ethylidene-1,5-dimethyl-3,3-diphenylpyrrolidene (EDDP), and methadone-induced corrected QT interval prolongation in a pilot study, Mol. Diagn. Ther 19 (2015) 131-138, 10.1007/s40291-015-0137-4. [PubMed: 25903311]

[88]. NCBI Resource Coordinators, Database resources of the National Center for Biotechnology Information, Nucleic Acids Res 44 (Database issue) (2016) D7-D19, 10.1093/nar/gkv1290. [PubMed: 26615191]

[89]. Eap CB, Broly F, Mino A, Hämmig R, Déglon JJ, Uehlinger C, Meili D, Chevalley AF, Bertschy G, Zullino D, Kosel M, Preisig M, Baumann P, Cytochrome P450 2D6 genotype and methadone steady-state concentrations, J. Clin. Psychopharmacol 21 (2001) 229-234, 10.1097/00004714-200104000-00016. [PubMed: 11270921]

[90]. Trescot AM, Faynboym S, A review of the role of genetic testing in pain medicine, Pain Physician 17 (2014) 425-445. [PubMed: 25247900]

[91]. Coller JK, Joergensen C, Foster DJ, James H, Gillis D, Christrup L, Somogyi AA, Lack of influence of CYP2D6 genotype on the clearance of (R)-, (S)-and racemic-methadone, Int. J. Clin. Pharmacol. Ther 45 (2007) 410-417, 10.5414/CPP45410. [PubMed: 17725248]

[92]. Lamba JK, Lin YS, Schuetz EG, Thummel KE, Genetic contribution to variable human to variable human CYP3A-mediated metabolism, Adv. Drug Deliv. Rev 54 (2012) 1271-1294, 10.1016/j.addr.2012.09.017.

[93]. Foster DJ, Somogyi AA, Bochner F, Methadone N-demethylation in human liver microsomes: lack of stereoselectivity and involvement of CYP3A4, Br. J. Clin. Pharmacol 47 (1999) 403-412, 10.1046/j.1365-2125.1999.00921.x. [PubMed: 10233205]

[94]. De Fazio S, Gallelli L, De Siena A, De Sarro G, Scordo MG, Role of CYP3A5 in abnormal clearance of methadone, Ann. Pharmacother 42 (2008) 893-897, 10.1345/aph.1K539. [PubMed: 18460585]

[95]. Jurica J, Sulcova A, Determination of Cytochrome P450 Metabolic Activity Using Selective Markers, Topics on Drug Metabolism, in: Paxton James, Dr. (Ed.), InTech, 2012 Available from: $<$ https://www.intechopen.com/books/topics-on-drug-metabolism/determination-of-cytochromep450-metabolic-activity-using-selective-markers >. doi: 10.5772/30236.

[96]. Tamási V, Falus A, Genetic and Epigenetic Factors Affecting Cytochrome P450 Phenotype and Their Clinical Relevance, Topics on Drug Metabolism, in: Paxton James, Dr. (Ed.), ISBN: 978953-51-0099-7, InTech, 2012 Available from: < http://www.intechopen.com/books/topics-ondrug-metabolism/genetic-and-epigenetic-factors-affecting-cytochrome-p450-phenotype-andtheir-clinical-significance $>$.

[97]. Richards-Waugh LL, Primerano DA, Dementieva Y, Kraner JC, Rankin GO, Fatal methadone toxicity: potential role of CYP3A4 genetic polymorphism, J. Anal. Toxicol 38 (2014) 541-547, 10.1093/jat/bku091. [PubMed: 25217544]

[98]. Yang HC, Chu SK, Huang CL, Kuo HW, Wang SC, Liu SW, Ho IK, Liu YL, Genome-wide pharmacogenomic study on methadone maintenance treatment identifies SNP rs17180299 and multiple haplotypes on CYP2B6, SPON1, and GSG1L associated with plasma concentrations of methadone R- and S-enantiomers in heroin-dependent patients, PLoS Genet 12 (2016) e1005910, 10.1371/journal.pgen.1005910. [PubMed: 27010727] 


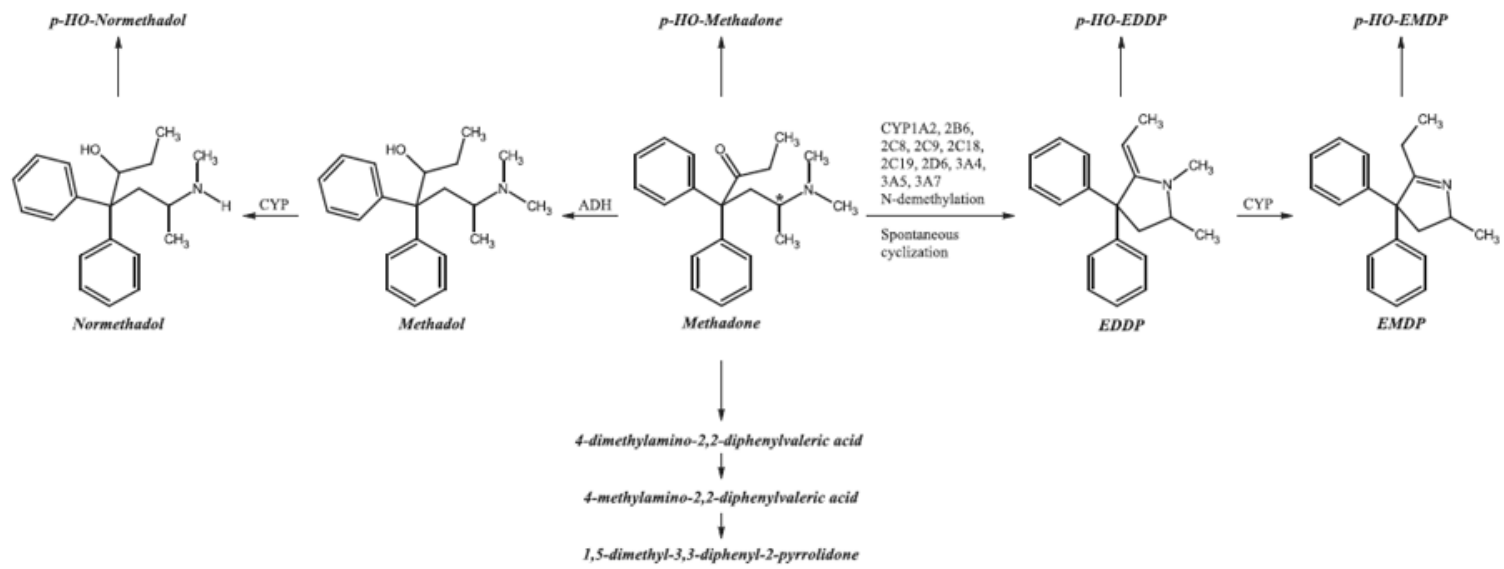

Fig. 1.

Eleven methadone metabolites found in human excretion. *Indicates chiral carbon atom. ADH, alcohol dehydrogenase; CYP, cytochrome P450; EDDP, 2-ethyl-1,5-dimethyl-3,3diphenylpyrrolidine; EMDP, 2-ethyl-5-methyl-3,3-diphenyl-1-pyrroline; p-HO, parahydroxy. 


\section{Table 1}

Cytochrome P450 single nucleotide polymorphisms relevant to methadone metabolism.

\begin{tabular}{|c|c|c|c|c|c|}
\hline Alleles & dbSNP ID ID $^{\dagger}$ & Key sequence change & $\begin{array}{l}\text { Effect and key } \\
\text { amino acid } \\
\text { substitution (if } \\
\text { any) }\end{array}$ & Effect on enzyme activity & Ref. \\
\hline$C Y P 1 A 2 * 1 F$ & rs762551 & $\begin{array}{l}\text { intron 1, c. }-9-154 \mathrm{C}> \\
\text { A }\end{array}$ & & $\begin{array}{l}\text { No influence on }(\mathrm{R})-,(\mathrm{S})-\text {, or } \\
\text { (R,S)-MTD levels at trough or } \\
\text { peak }\end{array}$ & [64] \\
\hline$C Y P 2 B 6^{*} 2$ & rs8192709 & c. $64 \mathrm{C}>\mathrm{T}$ & $\mathrm{R} 22 \mathrm{C}$ & $\uparrow[(\mathrm{R}, \mathrm{S})-\mathrm{MTD}] /[\mathrm{EDDP}]$ ratio & [72] \\
\hline \multirow[t]{4}{*}{ CYP2B6*4 } & rs2279343 & c. $785 \mathrm{~A}>\mathrm{G}$ & K262R & $\uparrow(\mathrm{R}, \mathrm{S})$-MTD plasma levels & {$[73,74]$} \\
\hline & & & & $\downarrow(\mathrm{R}, \mathrm{S})$-MTD plasma levels & {$[75,76]$} \\
\hline & & & & $\uparrow$ MTD clearance & \\
\hline & & & & $\begin{array}{l}\uparrow(\mathrm{R})-\text { and (S)-MTD N- } \\
\text { demethylation }\end{array}$ & \\
\hline \multirow[t]{4}{*}{ CYP $2 B 6^{* 5}$} & rs3211371 & c. $1459 \mathrm{C}>\mathrm{T}$ & $\mathrm{R} 487 \mathrm{C}$ & $\downarrow$ (S)-MTD plasma levels & [32] \\
\hline & & & & $\uparrow(\mathrm{S})$-MTD clearance & \\
\hline & & & & No effect on MTD clearance & [75] \\
\hline & & & & $\uparrow(\mathrm{R}, \mathrm{S})$-MTD plasma levels & [72] \\
\hline \multirow[t]{4}{*}{$C Y P 2 B 6^{*} 6$} & rs2279343 & c. $785 \mathrm{~A}>\mathrm{G}$ & K262R & $\begin{array}{l}\uparrow(\mathrm{S}) \text { - and (R,S)-MTD plasma } \\
\text { levels }\end{array}$ & {$[64,67,75-79]$} \\
\hline & rs 3745274 & c. $516 \mathrm{G}>\mathrm{T}$ & Q172H & $\uparrow \mathrm{MTD} /$ Dose plasma ratio & \\
\hline & & & & $\begin{array}{l}\downarrow \text { (R)- and (S)-MTD N- } \\
\text { demethylation }\end{array}$ & \\
\hline & & & & $\downarrow$ MTD clearance & \\
\hline \multirow[t]{4}{*}{ CYP2B6*9 } & rs3745274 & c. $516 \mathrm{G}>\mathrm{T}$ & Q172H & $\uparrow(\mathrm{R}, \mathrm{S})-\mathrm{MTD}$ plasma levels & {$[74,76,80]$} \\
\hline & & & & $\begin{array}{l}\uparrow[(\mathrm{S})-\mathrm{MTD} / \mathrm{MTD} \text { Dose }] \text { plasma } \\
\text { ratio }\end{array}$ & \\
\hline & & & & $\begin{array}{l}\downarrow \text { (R)- and (S)-MTD N- } \\
\text { demethylation }\end{array}$ & \\
\hline & & & & $\downarrow$ (S)-MTD clearance & \\
\hline \multirow[t]{2}{*}{ CYP2B6*11 } & rs35303484 & c. $136 \mathrm{~A}>\mathrm{G}$ & $\mathrm{M} 46 \mathrm{~V}$ & $\uparrow(\mathrm{S})$-MTD plasma levels & [32] \\
\hline & & & & $\downarrow$ (S)-MTD clearance & \\
\hline \multirow[t]{2}{*}{ CYP2B63'UTR } & rs707265 & c. $* 1355 \mathrm{~A}>\mathrm{G}$ & & $\begin{array}{l}\uparrow[(\mathrm{S})-\mathrm{MTD} / \mathrm{MTD} \text { Dose }] \text { plasma } \\
\text { ratio }\end{array}$ & [80] \\
\hline & & & & $\downarrow(S)$-MTD clearance & \\
\hline \multirow[t]{2}{*}{ CYP2B63'UTR } & rslO38376 & 3'UTR, c.*1277A > T & & $\begin{array}{l}\uparrow[(\mathrm{S})-\mathrm{MTD} / \mathrm{MTD} \text { Dose }] \text { plasma } \\
\text { ratio }\end{array}$ & [80] \\
\hline & & & & $\downarrow$ (S)-MTD clearance & \\
\hline \multirow[t]{2}{*}{ CYP2B6 intron 1} & rs10403955 & c. $172-468 \mathrm{~T}>\mathrm{G}$ & & $\begin{array}{l}\uparrow[(\mathrm{S})-\mathrm{MTD} / \mathrm{MTD} \text { Dose }] \text { plasma } \\
\text { ratio }\end{array}$ & [80] \\
\hline & & & & $\downarrow(\mathrm{S})$-MTD clearance & \\
\hline \multirow[t]{2}{*}{ CYP2B6 intron 5} & rs2279345 & c. $923-197 \mathrm{~T}>\mathrm{C}$ & & $\begin{array}{l}\uparrow[(\mathrm{S})-\mathrm{MTD} / \mathrm{MTD} \text { Dose }] \text { plasma } \\
\text { ratio }\end{array}$ & [80] \\
\hline & & & & $\downarrow$ (S)-MTD clearance & \\
\hline \multirow[t]{2}{*}{$C Y P 2 C 9 * 2$} & rs1799853 & c. $430 \mathrm{C}>\mathrm{T}$ & $\mathrm{R} 144 \mathrm{C}$ & No effect on MTD plasma levels & {$[64,77,82]$} \\
\hline & & & & $\uparrow \mathrm{MTD} /$ Dose plasma ratio & [78] \\
\hline$C Y P 2 C 9 * 3$ & rs1057910 & c. $1075 \mathrm{~A}>\mathrm{C}$ & $\mathrm{I} 359 \mathrm{~L}$ & No effect on MTD plasma levels & {$[64,77,82]$} \\
\hline
\end{tabular}




\begin{tabular}{|c|c|c|c|c|c|}
\hline Alleles & dbSNP ID ${ }^{\dagger}$ & Key sequence change & $\begin{array}{l}\text { Effect and key } \\
\text { amino acid } \\
\text { substitution (if } \\
\text { any) }\end{array}$ & Effect on enzyme activity & Ref. \\
\hline & & & & $\uparrow$ MTD/Dose plasma ratio & [78] \\
\hline \multirow[t]{4}{*}{ CYP2C19*2 } & $\mathrm{rs} 4244285$ & c. $681 \mathrm{G}>\mathrm{A}$ & I331V; splicing defect & No effect on MTD plasma levels & {$[64,77,82]$} \\
\hline & & & & $\uparrow(\mathrm{R})$-MTD plasma levels & {$[78,86]$} \\
\hline & & & & $\uparrow \mathrm{MTD} /$ Dose plasma ratio & \\
\hline & & & & $\uparrow$ EDDP plasma levels & [87] \\
\hline \multirow[t]{2}{*}{ CYP2C19*3 } & rs4986893 & c. $636 \mathrm{G}>\mathrm{A}$ & W212X; stop codon & No effect on MTD plasma levels & {$[64,77]$} \\
\hline & & & & $\uparrow \mathrm{MTD} /$ Dose plasma ratio & {$[78]$} \\
\hline$C Y P 3 A 4 * 1 B$ & rs2740574 & $\begin{array}{l}\text { 5'UTR, C, } \\
-392 \mathrm{~A}>\mathrm{G}\end{array}$ & & $\uparrow(\mathrm{S})$-MTD plasma levels & [64] \\
\hline \multirow[t]{4}{*}{$C Y P 3 A 5 * 3$} & rs776746 & $\begin{array}{l}\text { 5'UTR, } \\
\text { c.219-237A > G }\end{array}$ & Splicing defect & No effect on MTD plasma levels & {$[64,82]$} \\
\hline & & & & $\uparrow$ MTD metabolism & [94] \\
\hline & & & & $(* 1 / * 3$ carrier $)$ & \\
\hline & & & & $\begin{array}{l}\uparrow \mathrm{MTD} / \text { Dose plasma ratio } \\
(* 3 / * 3)\end{array}$ & [78] \\
\hline
\end{tabular}

More comprehensive information is available from the Human Cytochrome P450 Allele Nomenclature Committee [69].

CYP, cytochrome P450; MTD, methadone; EDDP, 2-ethyl-1,5-dimethyl-3,3-diphenylpyrrolidine; UTR, untranslated region.

${ }^{\dagger}$ National Center for Biotechnology Information (NCBI) dbSNP [88].

Location of sequence change on mRNA for the respective CYP NM accession number [88]. 


\section{Table 2}

Cytochrome P450 2D6 and their corresponding activity and phenotype.

\begin{tabular}{|c|c|c|c|c|c|c|}
\hline Alleles & $\operatorname{dbSNP}$ ID $^{\dagger}$ & Key sequence change & $\begin{array}{l}\text { Effect and key } \\
\text { amino acid } \\
\text { substitution (if } \\
\text { any) }\end{array}$ & Effect on enzyme activity & Phenotype & Ref. \\
\hline$C Y P 2 D 6 * 1$ & & & & $\begin{array}{l}\text { Wild type Duplication of } \\
\text { gene }\end{array}$ & EM & {$[57,64,82,89,91]$} \\
\hline \multirow[t]{3}{*}{$C Y P 2 D 6 * 1 x N$} & & & & Multiduplication of gene & UM & {$[64,82,91]$} \\
\hline & & & & $N$ active genes & & \\
\hline & & & & $\uparrow$ activity & & \\
\hline \multirow[t]{2}{*}{$C Y P 2 D 6 * 2$} & rs16947 & c. $886 \mathrm{C}>\mathrm{T}$ & $\mathrm{R} 296 \mathrm{C}$ & Normal activity & EM & {$[57,82,89,91]$} \\
\hline & rsl 135840 & c. $1457 \mathrm{G}>\mathrm{C}$ & $\mathrm{S} 486 \mathrm{~T}$ & Duplication of gene & & \\
\hline \multirow[t]{3}{*}{$C Y P 2 D 6 * 2 \times N$} & & & & Multiduplication of gene & $\mathrm{UM}$ & [82] \\
\hline & & & & $N$ active genes & & \\
\hline & & & & $\uparrow$ activity & & \\
\hline$C Y P 2 D 6 * 3$ & rs3574686 & c.775delA & 259Frameshift & Defective allele & PM & {$[64,82,89,91]$} \\
\hline \multirow[t]{5}{*}{$C Y P 2 D 6 * 4$} & rsl 065852 & c. $10 O C>\mathrm{T}$ & P34S & Defective allele & PM & {$[57,64,82,89,91]$} \\
\hline & rs28371703 & c. $271 \mathrm{C}>\mathrm{A}$ & L91M & & & \\
\hline & rs28371704 & c. $281 \mathrm{~A}>\mathrm{G}$ & H94R & & & \\
\hline & rs3892097 & c. $506-1 \mathrm{G}>\mathrm{A}$ & Splicing defect & & & \\
\hline & rsl 135840 & c. $1457 \mathrm{G}>\mathrm{C}$ & S486T & & & \\
\hline$C Y P 2 D 6 * 4 x N$ & & & & $\begin{array}{l}\text { Defective allele } \\
\text { Multiduplication of gene }\end{array}$ & PM & [91] \\
\hline$C Y P 2 D 6 * 5$ & & & & $\begin{array}{l}\text { Deletion of entire CYP2D6 } \\
\text { gene }\end{array}$ & PM & {$[57,64,91]$} \\
\hline$C Y P 2 D 6 * 6$ & rs5030655 & c. 454 delT & 118Frameshift & Defective allele & PM & {$[64,82,89,91]$} \\
\hline$C Y P 2 D 6 * 7$ & rs5030867 & c. $971 \mathrm{~A}>\mathrm{C}$ & $\mathrm{H} 324 \mathrm{P}$ & Defective allele & $\mathrm{PM}$ & [91] \\
\hline \multirow[t]{3}{*}{$C Y P 2 D 6 * 8$} & rs5030865 & c. $505 \mathrm{G}>\mathrm{A}$ & G169R & Defective allele & PM & [91] \\
\hline & rsl 6947 & c. $886 \mathrm{C}>\mathrm{T}$ & $\mathrm{R} 296 \mathrm{C}$ & & & \\
\hline & rsl 135840 & c. $1457 \mathrm{G}>\mathrm{C}$ & $\mathrm{S} 486 \mathrm{~T}$ & & & \\
\hline$C Y P 2 D 6 * 9$ & rs5030656 & c.841_843delAAG & K281del & Impaired function & $\mathrm{IM}$ & [91] \\
\hline \multirow[t]{2}{*}{ CYP2D6*10 } & rsl 065852 & c. $10 O C>\mathrm{T}$ & $\mathrm{P} 34 \mathrm{C}$ & Impaired function & IM & {$[57,91]$} \\
\hline & rsl 135840 & c. $1457 \mathrm{G}>\mathrm{C}$ & $\mathrm{S} 486 \mathrm{~T}$ & & & \\
\hline CYP2D6*16 & & CYP2D7/2D6 hybrid & $\begin{array}{l}\text { Frameshift; } \\
\text { switch region } \\
\text { exon7-intron } 8\end{array}$ & & PM & [91] \\
\hline \multirow[t]{3}{*}{$C Y P 2 D 6 H * 17$} & rs28371706 & c. $320 \mathrm{C}>\mathrm{T}$ & T107I & Impaired function & $\mathrm{IM}$ & [57] \\
\hline & rsl 6947 & c. $886 \mathrm{C}>\mathrm{T}$ & $\mathrm{R} 296 \mathrm{C}$ & & & \\
\hline & rsl 135840 & c. $1457 \mathrm{G}>\mathrm{C}$ & $\mathrm{S} 486 \mathrm{~T}$ & & & \\
\hline \multirow[t]{4}{*}{$C Y P 2 D 6 * 28$} & rs78482768 & $19 \mathrm{G}>\mathrm{A}$ & V7M & Unknown & Unknown & [91] \\
\hline & rsl 6947 & c. $451 \mathrm{C}>\mathrm{G}$ & Q151E & & & \\
\hline & rsl 135840 & c. $886 \mathrm{C}>\mathrm{T}$ & $\mathrm{R} 296 \mathrm{C}$ & & & \\
\hline & & c. $1457 \mathrm{G}>\mathrm{C}$ & S486T & & & \\
\hline \multirow[t]{2}{*}{ CYP2D6*29 } & rs61736512 & c. $406 \mathrm{G}>\mathrm{A}$ & V136I & Impaired function & IM & [57] \\
\hline & rsl 6947 & c. $886 \mathrm{C}>\mathrm{T}$ & $\mathrm{R} 296 \mathrm{C}$ & & & \\
\hline
\end{tabular}




\begin{tabular}{|c|c|c|c|c|c|c|}
\hline Alleles & $\operatorname{dbSNP}_{\mathrm{ID}^{\dagger}}^{\dagger}$ & Key sequence change ${ }^{*}$ & $\begin{array}{l}\text { Effect and key } \\
\text { amino acid } \\
\text { substitution (if } \\
\text { any) }\end{array}$ & Effect on enzyme activity & Phenotype & Ref. \\
\hline & rs59421388 & c. $1012 \mathrm{G}>\mathrm{A}$ & V338M & & & \\
\hline & rsl 135840 & c. $1457 \mathrm{G}>\mathrm{C}$ & $\mathrm{S} 486 \mathrm{~T}$ & & & \\
\hline CYP2D6*33 & rs28371717 & c. $709 \mathrm{G}>\mathrm{T}$ & A237S & Normal activity & EM & [91] \\
\hline \multirow[t]{3}{*}{ CYP2D6*35 } & rs769258 & c. $31 \mathrm{G}>\mathrm{A}$ & $\mathrm{V} 11 \mathrm{M}$ & Normal activity & EM & {$[57,82]$} \\
\hline & rsl 6947 & c. $886 \mathrm{C}>\mathrm{T}$ & $\mathrm{R} 296 \mathrm{C}$ & Duplication of gene & & \\
\hline & rsl 135840 & c. $1457 \mathrm{G}>\mathrm{C}$ & $\mathrm{S} 486 \mathrm{~T}$ & & & \\
\hline \multirow[t]{2}{*}{$C Y P 2 D 6 * 36$} & rsl 065852 & c. $1 \mathrm{OOC}>\mathrm{T}$ & P34S & Defective allele & $\mathrm{PM}$ & [57] \\
\hline & rsl 135840 & c. $1457 \mathrm{G}>\mathrm{C}$ & $\mathrm{S} 486 \mathrm{~T}$ & & & \\
\hline \multirow[t]{3}{*}{$C Y P 2 D 6 * 41$} & rsl 6947 & c. $886 \mathrm{C}>\mathrm{T}$ & $\mathrm{R} 296 \mathrm{C}$ & Impaired function & IM & [91] \\
\hline & rs28371725 & c. $985+39 \mathrm{G}>\mathrm{A}$ & Splicing defect & & & \\
\hline & rsl 135840 & c. $1457 \mathrm{G}>\mathrm{C}$ & $\mathrm{S} 486 \mathrm{~T}$ & & & \\
\hline \multirow[t]{2}{*}{$C Y P 2 D 6 * 43$} & rs28371696 & c. $77 \mathrm{G}>\mathrm{A}$ & $\mathrm{R} 26 \mathrm{H}$ & Normal activity & EM & [57] \\
\hline & & & & Duplication of gene & & \\
\hline \multirow[t]{3}{*}{ CYP2D6*45 } & rs 28371710 & c. $463 \mathrm{G}>\mathrm{A}$ & $\mathrm{E} 155 \mathrm{~K}$ & Normal activity & EM & [57] \\
\hline & rsl 6947 & c. $886 \mathrm{C}>\mathrm{T}$ & $\mathrm{R} 296 \mathrm{C}$ & Duplication of gene & & \\
\hline & rsl 135840 & c. $1457 \mathrm{G}>\mathrm{C}$ & $\mathrm{S} 486 \mathrm{~T}$ & & & \\
\hline
\end{tabular}

More comprehensive information is available from the Human Cytochrome P450 Allele Nomenclature Committee [69].

CYP, cytochrome P450; del, deletion; EM, extensive metabolizer; IM, intermediate metabolizer; PM, poor metabolizer; UM, ultra-rapid metabolizer.

National Center for Biotechnology Information (NCBI) dbSNP [88].

tLocation of sequence change on mRNA for the respective CYP NM accession number [88]. 